\title{
POSTCOLONIAL LITERARY CRITICISM AND GLOBAL WARMING
}

\begin{abstract}
Anne Maxwell
ABSTRACT

Postcolonial criticism generally has not had a strong history of engaging with environmental or ecological discourses but the prospect of global warming is likely to change this. It is likely to be particularly significant for postcolonial literary criticism, a discipline that in recent years has struggled to make itself relevant to the task of opposing globalisation. Some postcolonial literary critics have already begun using the arguments and concepts drawn from environmental discourses and ecocriticism, and in doing so they have contributed powerfully to the postcolonial critique of globalisation; however, to date few postcolonial critics have thought to use these same arguments and concepts to analyse fictions that speculate on the social effects of global warming. Taking a short story by a leading Australian author that is set in the year 2035, the last half of the article sets out to demonstrate the political potential of such a critical approach and the value of reading apocalyptic speculative fictions in particular.
\end{abstract}

\section{POSTCOLONIAL LITERARY CRITICISM AND GLOBAL WARMING}

Since its inception as a field of criticism in the 1970s, postcolonialism has consistently taken as one of its primary aims the opposing of all colonial values and forms of representation. Whether or not it has always achieved this goal is highly questionable, and this in turn has led some scholars to believe that there are currently several forms of postcolonialism, some of them more vitally opposed than others to the latest phase of capitalism, sometimes referred to as globalisation. Yet even if we acknowledge this situation of multiplicity, it remains the case that postcolonial criticism has not had a strong history of engaging with environmental or ecological concerns. With recent changes of temperature already starting to affect water availability and food production in many parts of the world, not to mention people's traditional habitats and 
lifestyles, this situation is almost certain to change, and with such change will come a whole new set of disciplinary priorities organised around the question of postcolonialism's contribution to the new world order that is likely to follow in globalisation's wake. For scholars, like myself, working in the field of postcolonial literary criticism, this inevitable shift in the field gives rise to at least two important questions. Firstly, given the many different meanings and practices that have accumulated around the term 'postcolonial' over the last twenty or so years, what form is this new type of criticism likely to take; and secondly, will there be a role for postcolonial literary criticism as such?

A so-called crisis of relevancy has been overhanging both postcolonial studies, and postcolonial literary criticism in particular, since the mid 199os. This is a crisis that has been given two types of articulation, although they each come back to the same problem of postcolonialism's ability to oppose globalisation. The first of these articulations occurred in 1994 at 'The Body in the Library Conference' held at the University of Queensland. John Frow's paper on the growing illegal trade in body parts sent a wake-up call to postcolonial scholars to turn their critical attention away from 'the construction of cultural and national identities' - an activity that had preoccupied them throughout the 1980s - and to focus instead on the new forms of human misery and oppression that globalisation was enacting. Such a change of direction, he argued, was necessary if postcolonialism was to remain a vibrant critical force in an age when the flow of culture, in addition to goods and capital, was no longing respecting national borders. But this wasn't the only feature of current postcolonial practice of which Frow was critical. He also attacked the preoccupation with the study of literature, arguing that this was setting unnecessary limits on the kinds of social and cultural critique postcolonialism was able to undertake:

Postcolonial theory owes its present vitality to the fact that it is coded as that place within the humanities disciplines where it is possible to talk about the third world. At the same time however - and with the major exception of such writers as Spivak and Bhabha - its restrictively literary concerns and its focus on culture-to-culture relations conceived as relations between an emergent nation-state and the former imperial nation-state, mean that it has largely failed to come to terms with the major explanatory accounts of these multi-layered ties of dependence -

I have in mind in particular contemporary theories of globalisation, current work in social geography, and world-systems theory (Frow, 1995: 98). 
In many ways Frow's comments reflected the changes that had been taking place in universities since the early 1990s, and which by the end of the decade had culminated in a fairly distinct division of labour between literary critics and theorists, but also the relocation of much postcolonial critique from English departments to disciplines like cultural studies, media studies, sociology and even politics, where the focus on nationalism had largely given way to the study of globalisation.

The second articulation came when Simon During distinguished what he calls a reconciliatory or celebratory model of postcolonialism from a critical model. The first he says owes its intellectual/political origins and allegiances to a broadly defined 'postmodern' left and is consequently not resistant to late capitalism. The second, by contrast, stands outside of and operates in opposition to the logic of late capitalism by maintaining, through various means, a commitment to Marxist and materialist analyses (During, 1998:32). ${ }^{1}$ Although During did not refer to the problem as being exacerbated by postcolonial literary criticism, as did Frow, he nevertheless implied that postcolonial literary critics were among those faced with the choice of remaining genuinely committed to decolonisation or becoming party to globalisation and capitalism's triumph. ${ }^{2}$

A decade out from During's comments, it seems the situation is shifting yet again. The focus on nationalism and the aftermath of empire has attained a new incarnation in the form of critiques directed against the United States' growing incursions on and occupation of foreign lands and sovereign territories following the September 11th 2001 terrorist attacks on the World Trade Centre and the Pentagon. There has also been a renewed interest in the work of Marxist intellectuals like Fredric Jameson and Noam Chomsky who, even before the September 11th attacks, had been arguing that the kind of critiques that have historically privileged the nation as a force for opposing imperial power, still have an important role to play in resisting some of the more politically belligerent and economically exploitative features of globalisation. ${ }^{3}$ At the same time, following in the wake of the example set by writers like Arundhati Roy, with her book The Cost of Living (1999); Ken Saro-Wira, with his poems exposing the havoc that the Shell Oil Company was having on Nigeria's Ogoni people; J. M. Coetzee with his book The Lives of Animals (1999); and Barbara Gowdy's The White Bone (1999), ${ }^{4}$ a new branch of postcolonial literary inquiry is emerging that draws heavily on that recently-birthed field of literary studies of the 1990 o - ecocriticism. The trend is obvious from the number of high profile postcolonial critics who have recently turned their attention in this direction, including Robert Young, Graham Huggan and Helen Tiffin, and the 
fact that recently there have been at least two academic conferences dedicated to the subject along with several journal articles and journal issues. ${ }^{5}$

The postcolonial literary critics just referred to are important for demonstrating how environmentalist discourse can be drawn on to produce a critical framework that is responsive to globalisation; however, none of these critics addresses the problem of global warming. To help develop such a criticism, I have drawn on three strands of environmentalist argument: the first is exemplified by the theoretical writings of history of science scholar and social philosopher Kate Soper, which examine and critically interrogate the distinction between ecological and postmodern ideas about nature; the second is represented by the empirically-based environmentalist critiques of Gustave W. Sauer and Bernd Hamm, which present us with the demographic and social facts of environmental change and its relation to globalisation, but which also seek to identify the root causes of these mounting problems; while the third is a literary critical tradition that studies early environmentalist writings in the context of European imperialism. This tradition takes the form of nature writing that portrays both nature and the human victims of environmental disasters in terms of an 'other' whose presence and demands can no longer afford to be ignored if life on earth as we know it is to continue. ${ }^{6}$

Soper's work is by and large theoretical and self-reflexive. Working across the disciplinary areas of philosophy and literature, its focus tends to be less on the political systems and institutions that are responsible for nature's exploitation by humans and more on the epistemological modes of thinking that lie behind this phenomenon - an approach that includes critically interrogating accepted ideas about nature and humans' relation to their natural environment. In particular, I look to Soper's call, in What is Nature? Culture Politics and the NonHuman (1995), to engage with what she calls the 'politics' of the idea of nature, to refer to the encounter between the two most influential perspectives on nature today. These are on the one hand the view of nature as discursive cultural construct, designated by 'nature', and on the other, the view of nature as an empirical reality that exists independently of human thought and language, a force or entity designated by Nature (Soper, 1995:3). For Soper, this is a tension that can be broadly construed as a contrast between postmodernist and ecological arguments respectively. As she puts it, the ecologists tend to invoke nature as a domain of intrinsic value, truth or authenticity, while postmodernist cultural theory and criticism looks with suspicion on any appeal to the idea as an attempt to eternalise what in reality is merely convention. But Soper insists that for her, this debate does not represent a political choice; rather, she views both positions - the 'nature endorsing' and the 'nature-sceptical' argu- 
ments - as equally legitimate. For example, positive elements of the ecological position include the advocacy of nature and the desire to respect as well as conserve valuable life forms, while positive aspects of the postmodern position include the critiques of nature's role in policing social, sexual and even racial norms. Significantly, Soper's study would appear to complicate During's claim that globalisation can only be opposed using materialist discourses, for she points to the periodic need to rescue the ecological position from the sorts of tyrannies and violences associated with the purely materialist position, while at the same time registering postmodernism's failure to observe the extrahuman dimension of nature's laws. As she herself puts it: 'although this might be construed as a contrast between ecological and postmodernist argument, my essential concern here is with the tension between diverging approaches to nature both of which may have a role to play in shaping a particular outlook' (Soper, 1995:4).

By contrast, Sauer and Hamm's recent essay 'Eco-Imperialism as an Aspect of Cultural Imperialism' (2005), is valuable precisely because it is so deeply grounded in materialist thinking, with all this implies for political commitment and agency. The essay relates the coming global crisis over environmental pollution and greenhouse gases, along with acute water and food shortages, to the neo-liberal economic policies of the more powerful western nations in particular. Sauer and Hamm see these contemporary policies as continuing in exactly the same spirit as the economic policies that were set up during the nineteenth century to augment the wealth of the European nations by exploiting both the labour and resources to be had from their overseas colonies. Having brought the planet's health to crisis point this century, such policies, in their view, are clearly not sustainable:

Our argument takes the form of first listing ten major aspects of the global problematique and giving a short account of the world's ecological and social situation. We then turn to demonstrating how this syndrome is related to neo-liberal corporate and governmental policies in hegemonic Western countries. From this analysis we conclude that the global crisis predicted by the Club of Rome to appear before 2100 is well underway. Poverty, diseases, and wars are mere symptoms of it. Until now World I has been relatively successful in exporting its own share of the crisis to World II and World III, but there are clear signs this is changing (Sauer and Hamm, 2005: 245-6).

In referring to the global crisis predicted by the Club of Rome, ${ }^{7}$ Sauer and Hamm's framework is essentially apocalyptic, and hence it could be said to 
be a touch melodramatic; on the other hand, it has the merit of informing us precisely who and what is responsible for this crisis and even what can be done about it. According to them, it is the institutions that have been set in place by neo-liberal western governments that are the primary sources of the problem, and insofar as such governments have been elected by the citizens of these nations, the institutions they create or endorse can be dismantled and replaced by more genuinely progressive ones. Hence the lives of people all over the planet are not so much at the mercy of the blind impersonal forces of capitalism, as some have claimed, as western society's own ignorance (or possibly indifference) towards the unsustainable nature of the policies and institutions that the west has so stubbornly been clinging to since the 1970 .

The reason is not that we do not know what to do in order to prevent the crisis, or that we lack the means to do so. All the necessary scientific, technical and social knowledge is there to be used. Indeed, it would not be difficult to design a world able to house some nine or ten billion human beings in a sustainable way or to sketch out the process of how we could get from here to there. The real obstacle is global power distribution and the ways our institutions are designed to produce the necessary decisions. That is, they have increasingly been brought under the influence of neo-liberalism since the late 1970 with the substantive support of western governments, exemplified, especially in the 1980s and 1990s, in the Thatcher, Reagan and Kohl regimes (Sauer and Hamm, 2005:245-6).

Also taking a more materialist approach is David Arnold's The Problem of Nature: Environment, Culture and European Expansion (2005), which both identifies and describes a long tradition of what can be loosely termed environmentalist thinking that has existed over the last thousand years, and the various ideological attitudes towards nature that have informed this tradition. What sets Arnold's work apart from Soper's is the fact that on top of confining his analysis of nature to the representations that have appeared in some of history's most important literary texts, he draws a direct analogy between the West's view of nature and its treatment of the colonised world. He refers, for example, to the fact that in western writing and scholarship it is not just alien landscapes and those untameable or intractable aspects of the physical environment that have refused to submit to human control that have been portrayed as 'other'; it is also non-western peoples and their cultures. A further feature of Arnold's study is its singling out of two different intellectual attitudes that currently exist towards the forces impacting negatively on present life forms. The first is the pessimistic response of those writers who attribute 
the destruction of the planet to the inherently rapacious nature of humanity itself, and who have consequently portrayed the relationship between nature and culture in 'bleak, dichotomised and unrelentingly Malthusian' terms. The second is the much more ambivalent and complex response of writers and thinkers who see nature not as some fixed or stable system along the lines of something like the Humboldtian 'harmoniously ordered whole', but as subject to slow evolutionary change and more rapid, even revolutionary, transformations (Arnold, 2005:56).

Continuing this line of thinking, but taking it further, is the literary critic Lawrence Buell, author of The Environmental Imagination (1995), which is essentially a study of Thoreau and nature writing in relation to American culture; and the more recent The Future of Environmental Criticism: Environmental Crisis and the Literary Imagination (2005), which pushes past the earlier focus on environment as 'nature', and on nature writing, to take into account what has become the normative world of the metropolis. Besides coining the term 'Toxic discourse' to describe the various forms of environmental poisoning that have taken place historically, Buell uses the term 'modern nature' to signal an awareness that the nature one engages with today is far from pristine. It is rather inescapably 'a mutual constitution of the natural and the social', where nature figures as something that has been modified (like it or not) by technology (Buell, 'Rhetoric of Toxicity', 639). As a scholar aiming to make literary criticism more answerable to environmental concerns, Buell himself propounds a view of nature that is 'neither preservationist nor conservationist, but aimed at achieving, as he puts it, an 'effective symbiosis with the physical environment' (639). From the point of view of postcolonial literary critics, however, perhaps the most useful element of Buell's thesis is his idea that effective environmentalist critique proceeds from a moral standpoint; hence the totalising rhetoric with which his claims about environmental poisoning are set forth. Hence, also, the moral melodrama that invariably characterises what he calls 'toxic discourse'. In fact, according to him, it is precisely because such narratives are melodramatic that they function as a vital recourse for those disempowered, marginalised groups who are seeking social justice.

This is of course to see both literature and literary criticism as crucial to today's discussions of environmental crises. In fact, Buell goes so far as to say they are no less fundamental than scientific research, technological know-how and legislative regulation precisely because of their explicit focus on issues of vision, value, culture and imagination - the very qualities needed if the old hierarchies that have brought the world to crisis are to be overturned and displaced (Buell, 2005:5). ${ }^{8}$ Ultimately then, Buell reminds us that the exploitation of nature lies 
at the heart of the question of social justice in the sense that it leads invariably to degraded urban landscapes, crimes against society's marginal groups, and the misuse of the human body and intellect (he himself uses an ecological economist's term 'environmentalism of the poor' to describe this phenomenon (Buell, 2005: 24). Finally, Buell makes it clear that the problem of social justice today does not depend simply on who has access to valuable resources like food and water in an era of increasingly diminishing availability; it also hinges on who is doing most to destroy those resources and who is prepared to take responsibility for the people who are missing out.

If, as Davison and Buell maintain, analysis of literary texts from the past helps us to understand the role played by both modernity and European colonialism in the depletion of the earth's natural resources and the extinction of various life forms, then analysis of texts set in the near future helps us to understand the role played by postmodernity and the forces of global capital in generating what some scientists refer to as one of the most dangerous forms of environmental catastrophe of all - global warming. So far in this essay, I have pointed to the crisis of relevancy that overtook postcolonial literary studies when in the early 1990 os it became evident that much of the scholarship being produced under this rubric was failing to engage with the many humanitarian problems that globalisation was producing. I have also described the kinds of environmentalist discourses that are useful to forging a postcolonial criticism aimed at opposing globalisation. In the following discussion, I concentrate on discerning what it is about fictions that try to imagine the future that renders them worthy of postcolonial critical attention. Rather than attempt to answer this question in a general sense, however, my method is to present a critical analysis of a literary text that addresses the subject of global warming using a postcolonial approach that draws selectively on the kinds of environmentalist concepts and arguments just outlined. The particular text I have chosen to analyse is 'The Fittest' (1990), a little-known short story by the popular Australian writer George Turner - a text whose political message remains surprisingly relevant despite the fact that it was published over twenty years ago.

Set in Australia's second-to-largest city, Melbourne, about twenty-five years from now when the ice caps have melted and the sea level has risen to the point of covering parts of the city, 'The Fittest' is about the widespread acts of inhumanity and the new kinds of social injustices that are beginning to erupt in 'developed' and 'undeveloped' nations alike as global warming really begins to take hold. Originally published in 1985 in a collection of stories ti- 
tled Urban Fantasies, ${ }^{9}$ it tells the story of a young man named Francis Conway who belongs to the class of people known as the Sweet. These are people who represent the privileged tenth of the city's population, the other disadvantaged ninety percent going by the name of the Swill. If the Sweet are privileged it is because despite the country's severely run-down economy, increasing lawlessness, and massive food and fresh water shortages, they still have jobs, which in turn enables them to live in the high-lying suburbs to the North and NorthEast where it is still possible to enjoy a relatively safe, pleasant lifestyle. The Swill, by contrast, being unemployed, inhabit the low-lying suburbs to the South and the West, including the area currently designated by Port Phillip Bay which includes Elwood, St Kilda and the inner city itself. Their presence is clearly marked on the skyline by a mass of high rise concrete tenement blocks, the lower floors of which are permanently submerged under sea water, while the middle floors are subject to the ocean's fluctuating tides.

The story is narrated primarily by Francis and is essentially about how he manages to avoid being plunged into poverty and the extremely harsh lifestyle that is the fate of the Swill, after his father commits suicide. Although readers are initially encouraged to identify with Francis, there comes a moment in the narrative when they realise that he is an essentially weak and selfish character. Confronted by his mother's illness and her impending death, he not only turns his back on her, but we see him refusing to face the truth about the reasons why so many Swill, including his mother, are falling ill and dying in such large numbers. When Francis's stepfather Billy Kovacs informs him that the deaths are not caused by the old AIDS virus that is spread by sexual contact or blood, but by a new virus that is spread by water vapour and air, and which has been deliberately placed by the state authorities in the public's drinking water to kill off the majority of the population, Francis refuses to believe him, insisting that as a Sweet he will always be safe. Apparently, for Francis, retaining his Sweet status is more important even than loyalty to family; it is also more important than facing up to certain fundamental truths about the collapsing global environment, including the knowledge that many Sweets have also been targeted for extinction.

Apart from Francis's selfishness, a further reason why the reader cannot fully identify with him is undoubtedly his flagrant class bias towards the Swill. By giving us two starkly opposed social groups in the form of the Sweet and the Swill, Turner would seem to be advancing the idea that despite the liberal policies of the present, Australian society still harbours classist sentiments left over from the colonial period (colonial Melbourne, it should be remembered, was basically comprised of a wealthy and poor class), ${ }^{10}$ and it will only take a 
crisis like the one of global warming to bring this to the fore once more. But he is also suggesting that in those situations where one population presides over, ruthlessly exploits and demoralises another, class differences are expressed in terms of racism. To Francis's way of thinking, the Swill belong to a different and much more primitive race, even though they are white. That he accords them a brute status is clear from his unconscious use of animal imagery. Chased by a gang of Swill in his youth, for example, he remembers thinking: 'My clothes, of course. I wore enough on my back to feed the pack of them for weeks' (Turner, 1990: 185); and his denigration of the gang leader's accent: 'He called out "wotser nyme, Sweetie?" The Swill accent can't be written down; it is far worse than any triv actor's imitation, barely understandable.' (p.185)

On the other hand, Turner also makes it clear that Francis harbours no fondness towards the people he calls 'the Ant-Hordes of Asia, forced out of their paddy fields' into Australia 'by swarming fecundity' (p.178). These people, according to Francis, are responsible for destroying Australia's vast areas of desert in their desperation to feed their teeming numbers.

The yellow man, born of centuries of harsh subsistence, made the desert bloom (sparsely) by introducing a torrential rainfall program which disrupted planetary weather until international rumblings forced moderation; then he poured megatonnes of liquid fertiliser into the soil, and, in a few years, polluted not only the coastal water table but also the artesian reservoirs underground. Water, already in controlled supply, became as scarce in Australia as in the rest of the world; expensive iceberg tows and desalination projects brought desperate governments closer to bankruptcy. So there were a hundred million people living, after a fashion, on a country capable of supporting a third of them in a reasonable manner (p.178).

This passage underlines Francis's dislike of Asian migrants and suggests humans' gross irresponsibility towards the environment and nature; for not only are we presented with an image of nature being forced to over-produce to the point where the soil is emptied of nutrients (if it hasn't already been rendered lifeless by being poisoned), but we are apprised of the problem of over-population, with the Asian countries in particular being singled out as failing to restrict their numbers to what is environmentally sustainable.

As if to underline the extent to which Francis's values are the product of choice and not compulsion, even in a society that has fallen into chaos, the narrative presents us with two other major characters who make a point of treating 'the 
other' with more compassion and care. Both Francis's older brother, Teddy, and his stepfather Billy Kovacs, serve as intermediaries between the Sweet and the Swill. They offer assistance to members of both classes while also attempting to dismantle the material and ideological barriers separating the two groups. Teddy, although a Sweet by birth, works for an organization known as the Intelligence Group - essentially a vigilante force whose job it is to try and curb the wanton and violent killings that are taking place everyday in Swill territory as people fight one another for food, clothing and dry space, and to lend physical and emotional assistance to the victims of Swill crime.Billy on the other hand, is not averse to mixing with Sweets, even though he was born a Swill. It is he, for example, who rescues Francis when he is chased by the gang of Swill youth, and who arranges for him to secure the high-paying job that allows him to remain living in Sweet territory. He also marries Francis's mother and nurses her when she falls victim to the AIDs virus. And yet while each in their own way transcends the reigning culture of overt racism and violence, neither Teddy nor Billy is portrayed as completely faultless. Teddy, for example, fails to take responsibility for his mother and his younger brother when, as a result of the father's suicide, their sole source of income dries up. One consequence of his neglect is that Francis must go out to work for a government that supports criminal activities while still only a child. He also grows up believing that the only thing that matters in life is achieving and maintaining one's own financial security. As for Billy, he may be a caring husband and stepfather, but he is also a cunning opportunist who earns his living extorting protection money from the Sweet, including initially Francis's and Teddy's mother.

The ambiguous manner in which Turner portrays Teddy and Billy may be his way of registering uncertainty over whether or not the people of Australia (and by implication humans generally) will manage to avoid self-destruction by curbing their instinct to ruthlessly colonise and exploit both other humans and the natural world. Moreover, in the story, what we might call the self-destructive instinct is not just attributed to individuals; as with Sauer and Hamm, it is also traceable to the economic forces and political institutions that uphold modern-day society, only here it is not so much the big corporations that are singled out for blame as the modern welfare state. In so far as the imaginary state of the future offers its downtrodden citizens some degree of protection from Swill violence (as the vigilante force to which Teddy belongs, testifies), it can claim to be caring. However, this same system also harbours corrupt personnel like Mrs Parkes, the Big Sweet heading up the administration. She not only illegally siphons off money from the public purse by channelling it into her own account and those of her friends', but she unabashedly hires Francis to disguise the fact. Moreover, to the extent that it is the state that allows the 
money system in Australia to collapse, it could be said that Turner is judging it as largely responsible for the dire conditions of the Swill.

'The Fittest', with its Darwinian title evoking the struggle of the races to survive, formed the germ story for Turner's more complex novel The Sea and Summer (1987). The events of this novel are set even further (one thousand years, in fact) into the future, at a time when global warming no longer exists and the civilization that produced it is the subject of historical and archaeological study. Moreover, this time, the city of Melbourne is much smaller, reflecting a massive reduction in the world's population. It is also situated at the foot of the Dandenong hills among the trees where its citizens can gaze out over the tranquil waters now covering the old city. The weather pattern has completely changed too, the perpetual summer and dryness that was a feature of Francis's day having being replaced by seasons of rain and chill that make a plentiful supply of food possible once more. Most importantly, however, the denizens of the new city (they are called the 'Autumn People') are no longer divided into Sweet and Swill, and indeed regard the lifestyle their ancestors led as horrendously primitive as well as irresponsible. The novel is also much more explicit about the fact that it was the earlier peoples' stubborn and irresponsible refusal to reform the institutions and practices that undergirded their society that produced the phenomenon of runaway global warming. As the ferryman who takes passengers out to explore the ancient ruins of the old city, explains, 'they knew what was coming to them just as we know what is ahead of us, yet they did nothing about it.' (Turner, 1987:10). Why? Because

'they were bound into a web of interlocking systems-finance, democratic government, what they called high tech, defensive strategies, political bared teeth and maintenance of a razor-edged status-quo which plunged them from crisis to crisis as each solved problem spawned a nest of new ones... We use everything better. We live better, think better' (p.13).

By the time he wrote the novel it would have been theoretically possible for Turner to have developed an acute awareness of the part played in global warming by the neoliberal phase of capitalism that we today associate with globalisation. On the other hand, it's just as likely that the economic and political system singled out for blame by the ferryman is an allusion to the earlier system of capitalism that had been in place for most of the twentieth century if not several hundred years, and which even left-wing governments, owing to their privileging of democracy and their tendency to corruption, had been unwilling to seriously challenge. Either way, it seems that Turner saw human 
activity and in particular the self-serving lifestyle of the western nations as the main contributor to global warming, rather than the forces of nature.

Written when the Australian Labour Party was just beginning to extend its multicultural policy to Asians, and the Victorian government was building masses of ugly high-rise apartments for the unemployed in Melbourne's inner suburbs, 'The Fittest' is arguably heavy-handed in the way it sets about condemning what Turner sees as the irresponsible (because environmentally unsustainable) practices of many present-day western governments. It is also arguably overly-melodramatic, if not verging on the crude, in the way it portrays nature (mainly in the form of the avenging sea) as an all-powerful force that is wholly at odds with humanity, recalling Soper's observation about the need to attribute nature with cultural as well as empirical meaning, and the way it divides Australian society into Sweets and Swills, as if to evoke the überman and subhuman dichotomy of Nazi Germany. And yet for all this, the story is sobering for what it says about the moral choices that people will be forced to make, both now and in the not so distant future, if our physical environment begins to seriously heat up; especially whether or not to look after only oneself or to help those who are less fortunate; and whether or not to assume a responsibility for future generations. After all, as Clive Spash (2002) has pointed out, 'Who exists [in the future] and their life expectancy is conditional upon current decisions' (Spash, 2002: 244).

Nor should these choices be thought of as being beyond the power of individuals to control. As critics like Sauer and Hamm have argued, such moral choices are reflected in the kinds of leaders we elect to govern our society, and the kinds of institutions that these governments sanction and promote. While the short story suggests that the moral choices that individuals make will determine the fate of one particular society, the novel implies that such choices will determine the fate of human civilization as a whole. Read like this, the story's setting in Melbourne is somewhat incidental, the immense division between Sweet and Swill being indicative of social conditions globally, if not also directly echoing the division between the poorer nations of the South and the wealthy nations of the North.

The story is thought-provoking for what it says about the changed meanings that may soon attach to the concept of race. As we have seen, racial distinctions may have little to do with physical characteristics, people instead being stigmatised according to how they speak and where they can afford to live, and this in turn being determined by whether or not they are useful to the thoroughly ruthless economy that is likely to emerge in the wake of global 
warming. In addition, by having the reader identify with the very different political ideologies of firstly Francis and secondly Teddy, the story encourages a certain degree of self-reflexiveness. The sudden switch in point of view, for instance, forces the reader to question the accuracy of their perceptions, but it also draws attention to the implicit power of story-telling and speculative fiction in particular to shape people's values and attitudes.

Finally, in weighing up the story's merits, we should not forget Buell's observation that the most effective environmentalist critiques obtain their moral authority from the cultivation of a certain degree of emotional stridency. Their whole purpose is to alert people to the folly of their present course of action using the techniques of defamilarisation (hence the story's future setting), but also shock and aversion. This is particularly true of those speculative fictions in which a negative vision of the future is formed through the extrapolation or exaggeration of developments belonging to the present. ${ }^{11}$ In this case, if both story and novel are shocking, it is not just because the vision of the future they present is one of social disarray and collapse, it is also because the events take place in a city that is recognisable and familiar to many.

To come back to the question of postcolonial literary criticism's relevancy with which I began; I have been arguing that both environmentalist and postcolonial criticism wrestle with the problem of comportment toward 'the other', where that other is both nature and the people who have benefited least from capitalism's expansion; and that the combining of these discourses can generate a critical practice that is both highly responsive and resistant to globalisation. I have also been arguing that whereas the critical focus on literary texts from the past helps us to understand the role played by European colonialism (with its attendant structure of colonial capitalism) in the depletion of the earth's natural environment and the destruction of indigenous lifestyles and populations, analysis of fictional texts set in the near future can help us to better appreciate the damage done by the latest phase of capitalism known as globalisation to the earth's greenhouse atmosphere and the human race as a whole. It also assists us to perceive the long-term effects on society and on human relations of pursuing a lifestyle that takes no heed of how it affects the earth's atmosphere and the other life forms with which we share the planet.

Finally, I have been arguing that the value of reading speculative texts like Turner's lies in coming to a deeper understanding of the kind of world that is likely to form during even our own lifetime if global warming continues and if humans persist in treating the planet and its various life forms as endlessly expendable resources which are there to be raided and exploited for profit. 
Arguably even more importantly, reading such works helps us to appreciate the necessity of making the right kinds of political choices in the present in the knowledge that as with colonialism, the perpetuation of the institutions that support neo-liberalism can only lead to a toxic future.

NOTES

1 Benita Parry was arguably the first postcolonial critic to identify this crisis in the discourse. In her article 'Problems in Current Theories of Colonial Discourse' (1987), Parry claimed that there was a fundamental and potentially dangerous division forming between the critics who, using Marxist and materialist approaches, supported the exemplary practice of postcolonial liberation movements and those who like Spivak and Bhabha favoured the less politically engaged poststructuralist approach known as 'colonial discourse analysis'. On the other hand, Parry was not responding to the phenomenon of globalisation as such since her article appeared before the collapse of the Soviet Union.

2 Besides using the term globalisation as a synonym for late capitalism, During's argument would seem to assume a dark side to globalisation that resonates with Neil Lazarus's claim that 'globalization was never the deterritorialised and geopolitically anonymous creature that neo-liberal ideology projected it as being. On the contrary, it was from the outset a political project, a consciously framed strategy designed to restructure social relations world-wide in the interests of capital' (Lazarus, 11). Indeed, at one point in his essay During even refers to the connection that some critics have drawn between globalisation and 'US Imperialism'.

3 See, for example, their essays in the edited collection The Cultures of Globalization (2003).

4 As author of the The God of Small Things, the literary novel which in 1997 won the prestigious Booker Prize and a million dollar book deal, Roy was poised to become the next biggest selling Indian author in Britain and the UsA after Salman Rushdie. But she surprised fans and critics alike by turning her critical attention to the plight of the tribal people from Narmada Valley whose environment and traditional way of life have been destroyed by the construction of the Sadar Sarover dam, a project organised by the Indian government but funded by the largely American controlled World Bank to the tune of more than 450 million dollars. In a series of powerful, polemical essays she attacked India's pretensions to be a modernised, progressive state based on democratic principles, replacing this with a vision of India that sees millions of lives sacrificed for the 
luxury and comforts to be enjoyed by the few. See Roy's The Cost of Living (1999); Ken Saro-Wiwa's poems about the environmental devastation the western oil company was causing in Nigeria's oil-rich South-eastern Rivers State, contributed to him being be arrested in 1995, imprisoned and executed by Nigeria's military government despite international appeals for clemency; Coetzee's book The Lives of Animals (1999) defended the rights of animals to be treated humanely and with sympathy, while simultaneously pleading for the universal and compulsory adoption of vegetarianism. Gowdy's book The White Bone (1999) transforms the genre of the animal fable by getting inside the consciousness of elephants and showing what it is like to belong to a highly endangered species that is subject to large-scale massacres and mutilations at the hands of voracious humans.

5 See, for example, Robert Young's Postcolonialism: A Very Short Introduction (2003). Young singles out what he considers to be the exemplary postcolonial practices of the Landless Workers Movement in Anhembi, Brazil, the Chipko tree-huggers of Northern India and the local Narmada women of the Maheshwar province in India. These are all groups whose work overlaps with that of environmentalists. In the book's introduction Young writes that postcolonialism is 'a political practice that is morally committed to transforming the conditions of exploitation and poverty in which large sections of the world's population live out their daily lives' (Young 6). But then he adds that besides comprising a related set of perspectives, which are juxtaposed against one another, it 'involves issues that are often the preoccupation of other disciplines and activities, particularly to do with the position of women, of development, of ecology, of social justice, of socialism in its broadest sense' (Young 7); See also Graham Huggan's 'Greening Postcolonialism: Ecocritical Perspectives' (2004); Helen Tiffin's Five Emus to the King of Siam (2007), and her forthcoming book Postcolonial Ecocriticism (2008); Anthony Vita's 'Toward an African Ecocriticism: Postcolonial Ecology and The Life of Michael K', (2008). Conferences include the American Comparative Literature Association Conference 'Ecocriticism and its Postcolonial Futures', Princeton University, March 23-26, 2006; the 'Postcoloniality and Ecology Conference,' Centre for Research in Postcolonial and Transcultural Studies, Roehampton University, November 14-15, 2008; see also the special issue in 2008 on 'Postcolonialism and Ecocriticism,' Journal of Commonwealth and Postcolonial Studies.

6 I am aware that at various points my discussion appears to conflate the positions of environmentalists and ecologists who tend to have very different ideas concerning the causes of global warming and how the problem should be tackled. Generally speaking, in contrast to environmentalists and the various green 
movements, ecologists champion a more philosophical approach to environmental problems, but they also place more emphasis on other species, ecosystems and processes in nature. This invariably leads them into the realm of ethics and sometimes to that newly-birthed school of ecological thought described as deep ecology, which is concerned with fundamental philosophical questions about the role of human life within the ecosphere. Insofar as the postcolonialism that I am advocating draws less on scientistic approaches and more on philosophical and aesthetic ideas about nature, while also focusing on the ethical aspects of the political choices made by governments, corporations and individuals, it is probably edging closer to the ecological position.

7 The Club of Rome was the name of a think tank of scientists, economists, businesspeople, international civil servants, and politicians from five continents. It began in an informal way at the behest of Aurelio Peccei, an Italian businessman from Rome, and based its predictions around a book commissioned by the organization itself titled Limits to Growth (1972), which rather controversially challenged the assumption that the Earth was infinite and would provide the resources needed for human prosperity. The study had obvious limitations, some of which arose from the use of computer modelling. Nevertheless on many points, including the predictions about the death of plant and animal species, plus the inevitable exhaustion of fish stocks, and oil and water reserves, it seems that the warning remains valid.

8 Here Buell would appear to have at least two villains of the piece in mind; on the one hand he refers to the 'arrogance of humanism' (Buell, 2005:24), but on the other he also says that 'the privileged classes of the world inhabit a global 'risk society' whose hazards cannot be anticipated, calculated and controlled, much less escaped' (Buell, 2005:5), which I take to be an allusion to the neo-liberal policies of western governments.

9 See George Turner, 'The Fittest', in Urban Fantasies, eds. David King and Russell Blackford, Melbourne: Ebony Books, 1985. Reprinted in A Pursuit of Miracles 175-207. The citations used hereafter are from A Pursuit of Miracles. While he was alive, Turner was known in Australia as a talented writer of modernist fiction, winning several of the nation's most coveted literary awards for works produced in the 1960 s and 70 . In the 1980s, when Turner was nearing old age, he suddenly started writing futuristic fiction, a move which earned him little praise in Australia, but which won him fame in the Us A. Aside from The Sea and Summer, his most accomplished works from this late period are Brain Child (1991) The Destiny Makers (1993) and Genetic Soldier (1994), all of which are about humanity's future under the impact of genetic engineering. He died in 
1997. 'The Fittest' and The Sea and Summer were, as far as I know, his only works about global warming. For a more detailed account of George Turner's life and works see Judith Buckridge's, George Turner: A Life.

10 The wealthy class was educated and owned land; the poorer class by contrast was uneducated and comprised mostly of servants and the descendants of convicts, many of whom were from Southern London and Ireland. For an historical account of the class divisions that existed in Melbourne in the nineteenth century, see The Outcasts of Melbourne: Essays in Social History, eds. Graeme Davison, David Dunstan and Chris McConville. See also Patrick O'Farrell, The Irish in Australia, 1788 to the Present.

11 Writing about utopias, dystopias and anti-utopias Fredric Jameson has recently suggested that a fourth term or new generic category might be necessary to account for speculative fictions that working from the principle of 'if this goes on', present us with 'new maps of hell' and 'visions of total destruction', including sometimes 'the extinction of life on Earth.' According to Jameson this new category, which he signifies by the term 'apocalyptic', differs from dystopias like Orwell's 1984 in not having as its motivation disillusionment with utopian thinking. It also differs from critical utopias by not being contingent on 'a positive conception of human social possibilities whose effects are generated from Utopian ideals.' On the other hand, Jameson also makes it clear that in an age given over to globalisation, the sudden interest in Utopias marks a widespread search for large-scale political alternatives. See Jameson (2005) Archeologies of the Future, 198-99, and xiv-xv.

\section{REFERENCES}

Arnold, D. 2005 The Problem of Nature: Environment, Culture and European Expansion, Oxford: Blackwell.

Buckridge, J. 1999 George Turner: A Life, Melbourne: Melbourne University Press.

Buell, L. 1995 The Environmental Imagination: Thoreau, Nature Writing and the Formation of American Culture. Cambridge, MA: Belknap Press of Harvard University Press.

1998 'Toxic Discourse', Critical Inquiry 24(3): 639-665. 
2001 Writing for an Endangered World: Literature Culture and Environment, Cambridge: Belknap Press, Harvard University.

2005 The Future of Environmental Criticism: Environmental Crisis and Literary Imagination, Malden, MA: Blackwell.

Coetzee, J.M. 1999 The Lives of Animals, London: Profile.

Davison, G., D. Dunstan and C. McConville (eds). 1985 The Outcasts of Melbourne: Essays in Social History, Sydney: Allen and Unwin.

During, S. 1998 'Postcolonialism and Globalisation: A Dialectical Relation After all?' Postcolonial Studies, 1(1): 31-47.

Frow, J. 1995 'Private Parts: Body Organs in Global Trade', UTs Review, 1(2): 84100.

Gowdy, B. 1999 The White Bone, London: Flamingo.

Huggan, G. 2004 'Greening Postcolonialism: Ecocritical Perspectives', Modern Fiction Studies, 50(3): 701-33.

Jameson, F. 2005 Archaeologies of the Future: the Desire Called Utopia and Other Science Fictions, London: Verso.

Jameson, F. and N. Chomsky (eds). 2003 The Cultures of Globalization, Boston: MIT Press.

Lazarus, N. 2006 'Postcolonial Studies After the Invasion of Iraq', New Formations, 59:10-22.

O’Farrell, P. 2000 The Irish in Australia: 1788 to the Present, Sydney: unsw Press.

Parry, B. 1987 'Problems in Current Theories of Colonial Discourse', Oxford Literary Review, 9 (1-2): 27-58.

Pepper, D. 1993 Eco-Socialism: From Deep Ecology to Social Justice, London: Routledge.

Roy, A. 1999 The Cost of Living, New York: Modern Library. 


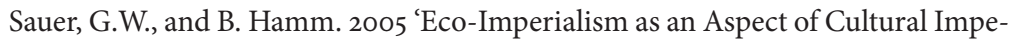
rialism', in Bernd Hamm and Russell Smandych (eds) Cultural Imperialism: Essays on the Political Economy of Cultural Domination, Toronto: Broadview Press: 244-64.

Soper, K. 1995 What is Nature? Culture Politics and the Non-Human, Oxford: Blackwell.

Spash, C.L. 2002 Greenhouse Economies: Value and Ethics, London: Routledge.

Tiffin, H. (ed). 2007 Five Emus to the King of Siam: Environment and Empire, Amsterdam: Rodopi.

Turner, G. 1990 'The Fittest', in A Pursuit of Miracles, Adelaide: Aphelion Publications: $175-207$.

1987 The Sea and Summer, London: Faber and Faber.

Vita, A. 2008 'Toward an African Ecocriticism: Postcolonial Ecology and "The Life of Michael K'", Research in African Literatures, 39(1): 87-106.

Young, R.J.C. 2003 Postcolonialism: A Very Short Introduction, Oxford: Oxford University Press. 